\title{
AL-A'RAF
}

Jurnal Pemikiran Islam dan Filsafat

SURAKARTA http://ejournal.iain-surakarta.ac.id/index.php/al-araf

ISSN: 1693-9867 (p); 2527-5119 (e)

\section{GENEALOGI DAN PENYEBARAN THARIQAH QADIRIYAH WA NAQSHABANDIYAH DI JAWA}

\author{
Aly Mashar \\ IAIN Surakarta
}

\begin{abstract}
$\longrightarrow$

Keywords:
Genealogy,
Tarekat, and
Thariqah Qadiriyah
wa Naqshabandiyah

Abstrak

Tulisan ini mengkaji tentang genealogi dan penyebaran Thariqah Qadiriyah wa Naqshabandiyah di Jawa. Pada beberapa literatur terdahulu (Dhofier, Martin van Bruinessen, Zulkifli, and Mulyati), dikemukakan bahwa di pulau Jawa genealogi tarekat bentukan Syekh Ahmad Khatib Sambas ini mengerucut pada tiga khalifah utamanya, yakni Syekh Abdul Karim Banten, Syekh Ahmad Thalhah Cirebon, dan Syekh Muhammad Hasbullah Madura, lalu menyebar ke seluruh pulau Jawa melalui empat pusat penyebaran (1970-an), yakni: Suryalaya, Rejoso, Mranggen, dan Pangentongan. Namun penulis menemukan bahwa terdapat empat khalifah, dengan tambahan Syekhona Kholil Bangkalan Madura; dengan sembilan pusat penyebaran (1970-an), dengan tambahan Berjan Purworejo, Sawah Pulo Surabaya, Cukir Jombang, Kencong Kediri, dan Dawe Kudus.
\end{abstract}

\begin{abstract}
This article investigates the geneology and spread of Thariqah Qadiriyah wa Naqshabandiyah in Java. Based on the previous literatures (Dhofier, Martin van Bruinessen, Zulkifli, and Mulyati), it was found out that in Java the genealogy of the thariqah formed by Syekh Ahmad Khatib Sambas directed to the three primary khalifah, i.e. Syekh Abdul Karim Banten, Syekh Ahmad Thalhah Cirebon, and Syekh Muhammad Hasbullah Madura, then spread out across Java Island through the four centers (on 1970s), such as Suryalaya, Rejoso, Mranggen, and Pangentongan. However, the writer found out that there were four khalifahs, including Syekhona Kholil Bangkalan Madura; with the nine dissemination centers (in 1970s) including Berjan Purworejo, Sawah Pulo Surabaya, Cukir Jombang, Kencong Kediri, and Dawe Kudus.
\end{abstract}




\section{Pendahuluan}

Tarekat Qadiriyah wa Naqshabandiyab (TQN) adalah sebuah tarekat yang dicetuskan oleh Syekh Ahmad Khatib Sambas (1803-1875), seorang ulama besar di Nusantara asal Sambas, Kalimantan Barat, yang telah lama menetap, bahkan sampai wafat di Mekah. Menurut Bruinessen, Syekh Ahmad Khatib Sambas mulai mengajarkan TQN ini sejak pertengahan abad ke-19 M. ${ }^{1}$

Pada paruh kedua abad19 M, hubungan antara Jawa dan Timur'Tengah sangat erat. Perkembangan alat transportasi kapal uap mempengaruhi banyak orang Jawa untuk menunaikan ibadah haji ke Mekah. Vredenbregt, sebagaimana dikutip Zulkifli, melaporkan bahwasannya jemaah haji asal Indonesia pada paruh kedua abad ke-19 M dan awal abad ke-20 M meningkat drastis. Antara tahun 1875 dan 1884 berjumlah 5.958 orang, sementara tahun 1905 dan 1914 mencapai 15.390 orang. Jumlah terbesar peziarah ini adalah dari Jawa, pada antara tahun 1875 dan 1884 terdapat 3.675 orang, dan antara tahun 1905 dan 1914 berjumlah 9.969 orang. Sebagian besar dari para peziarah ini tidak hanya melakukan Haji, namun tinggal beberapa waktu untuk memperdalam ilmu agama kepada beberapa ulama besar Nusantara yang telah lama menetap di sana, termasuk kepada Syekh Ahmad Khatib Sambas. ${ }^{2}$ Dalam situasi semacam ini, Syekh Ahmad Khatib Sambas tidak mengabaikan kesempatan untuk menyebarkan ajaran tarekatnya kepada para pelajar asal Nusantara, terutama Jawa. Bahkan dalam pengajaran TQN, beliau cenderung fokus kepada para pelajar Nusantara dibanding kepada para muridnya dari negara lain. Hal ini dibuktikan dengan mayoritas dari khalifah yang berasal dari Nusantara.

\footnotetext{
1 Martin Van Bruinessen, Kitab Kuning: Pesantren dan Tarekat (Bandung: Mizan, 1995), 214.

2 Zulkifli, Sufism in Java: The Role of Pesantren in The Maintenance of Sufism in Java (Jakarta: INIS, 2002), 31.
} 
Di Jawa, TQN disebarkan oleh dan melalui dari beberapa khalifah Syekh Ahmad Khatib, yakni Syekh Abdul Karim dari Banten, Syekh Tolhah dari Cirebon, dan Syekh Ahmad Hasbullah bin Muhammad alMaduri. ${ }^{3}$ Dari ketiga jalur ini, menurut Dhofier, pada tahun 1970-an terdapat empat pusat TQN di Jawa yang kesemuanya berafiliasi dengan pesantren: Rejoso, Jombang, Jawa Timur yang dipimpin oleh KH. Ramli Tamim yang mengambil jalur dari Syekh Ahmad Hasbullah; Suryalaya, Tasikmalaya, Jawa Barat yang dipimpin oleh KH. Shohibul Wafa Tajul Arifin yang mengambil jalur dari Syekh Tolhah Cirebon; Mranggen, Demak, Jawa Tengah yang dipimpim oleh KH. Muslih Abdurrahman; dan Pangentongan, Bogor Jawa, Barat yang dipimpin oleh KH. Thohir Falak. Kedua pusat TQN yang disebut terakhir mengambil jalur silsilah dari Syekh Abdul Karim Banten. ${ }^{4}$ Melalui jalur dan mata rantai tersebut, TQN menjadi salah satu tarekat yang popular dan memiliki anggota terbesar, mengalahkan jumlah anggota tarekat saingannya, Tarekat Naqshabandiyah Khalidiyah. $^{5}$

Berdasarkan uraian di atas, dalam tulisan ini penulis mencoba menguraikan genealogi dan penyebaran TQN di Jawa. Dari beberapa literatur dan data, penulis menemukan beberapa hal yang berbeda dengan kesimpulan Dhofier, Martin, Zulkifli, dan Mulyati. Perbedaanya terkait dengan jumlah khalifah penyebar pertama TQN di Jawa dan jumlah pusat penyebaran TQN pada era 1970-an. Dhofier dan para peneliti di atas menyimpulkan bahwa di Jawa hanya terdapat tiga khalifah yang membawa TQN ke Jawa, namun penulis menemukan adanya empat khalifah, dengan tambahan Syekhona Kholil Bangkalan, Madura, Jawa Timur. Selanjutnya, peneliti di atas juga menyatakan bahwa pada tahun 1970-an hanya ada

3 Sri Mulyati, et al, Mengenal dan Memahami Tarekat Tarekat Muktabarab di Indonesia (Jakarta: Kencana, 2006), 258-259.

4 Zamakhsyari Dhofier, Tradisi Pesantren: Studi tentang Pandangan Hidup Kiai (Jakarta: LP3ES, 1985), 95. 35.

5 Zulkifli, Sufism in Java: The Role of Pesantren in The Maintenance of Sufism in Java, 
empat pusat penyebaran TQN, namun penulis menemukan sembilan pusat, dengan tambahan TQN Berjan Purworejo, ${ }^{6}$ TQN Utsmaniyah Sawah Pulo Surabaya, TQN as-Shalihiyyah Dawe Kudus, TQN Cukir Jombang, dan TQN Kencong Kediri. Di sinilah fokus tulisan ini, menemukan hubungan sanad dari beberapa TQN tersebut baik sanad ke atas maupun ke bawah, serta para penerusnya hingga sekarang.

\section{Tarekat Qadiriyab Wa Naqsabandiyab}

TQN dicetuskan oleh Syekh Ahmad Khatib Ibnu Abdul Gaffar Sambas. Ia lahir di Sambas, Kalimantan Barat pada tahun 1802 M., dan ketika berusia sembilan belas tahun melanjutkan studinya ke Mekah dan menetap di sana hingga wafat pada tahun 1872 M. $^{7}$ Ia mempelajari dan menguasai pelbagai cabang keilmuan Islam, terutama Ilmu Tasawuf. Dalam Ilmu Tasawuf ia berguru kepada Syekh Daud ibn 'Abd Allah ibn Idris al Fatani (w.1843 M), Syekh Muhammad Arsyad al Banjari, Syekh 'Abd al Shamad al Palimbani, dan Syekh Syamsuddin. Dari beberapa gurunya ini, Syekh Syamsuddin lah yang banyak memengaruhi corak tasawuf Syekh Ahmad Khatib. Di mata Syekh Syamsuddin, Syekh Ahmad Khatib adalah murid paling unggul dibanding para murid lainnya. Oleh karena itu, Syekh Syamsuddin menetapkan Syekh Ahmad Khatib sebagai Syekh Mursyid Kamil Mukammil dan pengganti kepemimpinan tarekatnya setelah ia meninggal. ${ }^{8}$

Sebagaimana gurunya, Syekh Ahmad Khatib menjadi mursyid dari dua tarekat besar, yaitu Tarekat Naqshabandiyah dan Tarekat Qadiriyah. Namun, ia berbeda dengan para pendahulunya dalam proses pengajaran.

${ }^{6}$ Amelia Fauzia, Faith and the State: A History of Islamic Philanthropy in Indonesia (Leiden: Brill, 2013), 122-125.

7 Umar 'Abd al Jabbar, Siyar wa Tarajim ba'd 'Ulama'ina fi al Qarn al Rabi' 'Ashar lil Hijra (Jeddah: Tihama, 1982), 7.

8 Sri Mulyati, Tasawnf Nusantara: Rangkaian Mutiara Sufi Terkemuka (Jakarta: Kencana, 2006), 175-177.

9 Atika Ulfia Adlina, "Pengalaman Mistik Pengikut TQN Dawe Kudus", Jurnal Analisa, Vol. 19, No. 01, Januari - Juni (2012), 37-54. 
Para pendahulunya mengajarkan kedua tarekat tersebut secara terpisah, namun ia mengajarkannya sebagai satu kesatuan yang diamalkan secara utuh. Oleh karena hal itulah, menurut Van Bruinessen, tarekat yang diajarkan Syekh Ahmad Khatib dikatakan sebagai sebuah tarekat baru, dan dia sebagai pencetus awalnya. ${ }^{10}$

Rangkaian amalan TQN, sebagai sebuah tarekat gabungan, tersusun dari ajaran tarekat dasarnya, Tarekat Naqsyabandiyah dan Tarekat Qadiriyah. Sebagai contoh, amalan TQN yang paling mudah diketahui sebagai gabungan dari kedua tarekat tersebut ialah pada metode zikirnya. Dalam melakukan dzikir nafi wa ithbat, seorang pengikut TQN harus menggerakkan kepala dan membayangkan dzikir itu ditarik melalui alur badan. Lafadz la ditarik dari pusar ke otak, ilaha dari otak ke bahu kanan, lalu illallah dari bahu kanan dihujamkan ke arah jantung (lathifah al qalb). Selain lathifah al qalb yang terletak di jantung, zikir juga dipusatkan pada lima lathaif lainnya, yaitu lathifah al rub (di dada kanan), lathifah al sirri (dua jari di atas puting kiri), lathifah al khafi (dua jari di atas puting kanan), lathifah al akhfa (di tengah dada), dan lathifah al nafs al nathiqab (di otak). Alur gerak dari pusar ke otak hingga berakhir ke jantung adalah unsur pengaruh Tarekat Qadiriyah, sedangkan terkait lathaif adalah dari Tarekat Naqshabandiyah. Zikir tersebut bisa dilakukan dengan suara keras (jahr) sebagaimana Tarekat Qadiriyah maupun dengan tanpa suara (sirr) sebagaimana Tarekat Naqsyabandiyab. ${ }^{11}$ Selain itu, sebagaimana pernyataan Syekh Ahmad Khatib pada kitabnya, Kitab Fath Al'arifin, TQN juga mengandung unsur ajaran tarekat lain, yakni dari Tarekat Alanfas, Tarekat Aljunaydiyyah, dan Tarekat Almunafaqa. ${ }^{12}$

\section{Genealogi Tarekat Qadiriyab wa Naqsabandiyab di Jawa}

TQN di Jawa, seluruhnya bisa dilacak sanadnya kepada empat khalifah utama, Syekh Ahmad Khatib Sambas, yaitu: Syekh Abdul Karim, Syekh

10 Martin Van Bruinessen, Kitab Kuning: Pesantren dan Tarekat, 215.

11 Martin Van Bruinessen, Kitab Kuning: Pesantren dan Tarekat, 215.

12 Sri Mulyati, Tasawuf Nusantara: Rangkaian Mutiara Sufi Terkemuka, 178. 
Ahmad Tholhah, Syekh Ahmad Hasbullah, dan Syaekhona Kholil. Berikut penjelasan tentang masing-masing dari mereka dan para penerusnya.

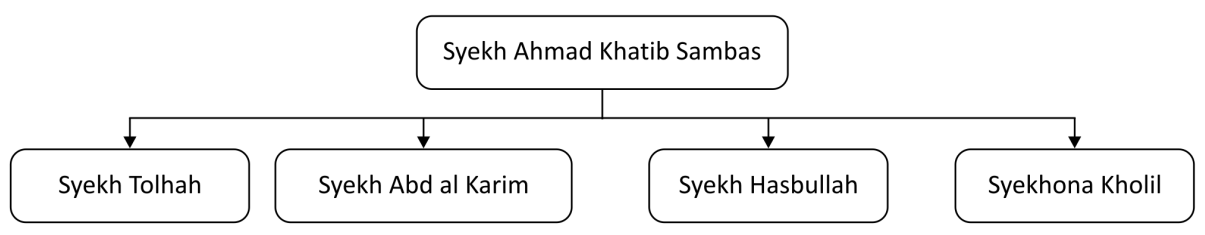

\section{Syekh Abdul Karim Albantani}

Syekh Abdul Karim adalah peletak pertama TQN di Jawa. Ia dilahirkan di Desa Lempuyang, Tanara, Banten, Jawa Barat pada tahun 1840 M. Nama orang tua dan masa pendidikan kecilnya tidak banyak diketahui, namun yang jelas dalam usia yang masih muda ia telah pergi ke Mekah untuk belajar agama kepada dan mengabdi di rumah Syekh Ahmad Khatib Sambas. ${ }^{13}$ Berkat ketekunan dan bimbingan dari gurunya yang tidak kenal lelah, Syekh Abdul Karim pun menjadi orang yang piawai dalam cabang ilmu tasawuf dan tarekat. Dari sinilah Syekh Ahmad Khatib mengangkatnya menjadi khalifah utama, dan ditetapkan sebagai calon pengganti kepemimpinan TQN sepeninggalnya.

Pada sekitar tahun $1872 \mathrm{M}$, Syekh Abdul Karim pulang dan mendirikan pesantren di tanah kelahirannya, Tanara, Banten. ${ }^{14}$ Tidak banyak diketahui nama dan letak persis pesantrennya, namun diinformasikan bahwa selain mengajarkan TQN di pesantrennya, ia juga sering berkeliling ke seluruh wilayah Banten guna mengajarkan cara berzikir dan ritual pembersihan jiwa. Hal inilah kiranya yang menjadikan pamor dan kharismanya tersebar dengan cepat ke seluruh Banten dan beberapa daerah sekitarnya. Dari situlah kemudian banyak murid berdatangan ingin mengecap ilmu dan belajar TQN kepadanya. Mereka tidak hanya berasal dari daerah sekitar

13 Sri Mulyati, Tasanuf Nusantara: Rangkaian Mutiara Sufi Terkemuka, 181.

14 Martin van Bruinessen, "Shari'a Court, Tarekat and Pesantren: Religious Institutions in the Banten Sultanate", dalam Archipel, Vol. 50, (1995), 165-199. 
Banten, tapi juga banyak yang dari daerah lain. ${ }^{15}$ Di antara murid dan khalifah Syekh Abdul Karim yang menonjol dan lahir dari pesantren ini ialah: Tubagus Muhammad Falak Pagentongan; Syekh Asnawi Caringin; Syekh Ibrahim al Brumbungi Demak; Tubagus Ismail, dan H. Mardjuki Banten. Dua nama yang disebut terakhir memiliki peran besar dalam peristiwa pemberontakan petani di Banten tahun 1888 M. ${ }^{16}$

Pada tahun 1876 M, sebelum pemberontakan petani terjadi, Syekh Abdul Karim diminta ke Mekah untuk memegang pucuk pimpinan TQN, menggantikan Syekh Ahmad Khatib Sambas. Sesampai di Mekah yang kedua kalinya ini, pengaruh Syekh Abdul Karim meningkat. Ia sangat dihormati oleh para ulama Mekah ketika itu, dan ditaati oleh seluruh khalifah Syekh Ahmad Khatib lainnya. Namun setelah ia meninggal dunia, TQN menjadi terpecah dengan kepemimpinan lokal. Tidak ada lagi pimpinan pusat yang ditaati oleh seluruh anggota TQN di seluruh dunia. ${ }^{17}$

Di Banten, sepeninggal Syekh Abdul Karim pergi ke Mekah yang kedua, penyebaran TQN diserahkan kepada Syekh Asnawi Caringin. Putra Syekh Asnawi, Kyai Khozim, menyebarkan TQN ke daerah Menes yang kemudian dilanjutkan oleh putranya, Kyai Ahmad. Pengakuan Kyai Khozim, ia tidak mendapatkan ijazah penuh dari ayahnya, namun ia dilantik sebagai khalifah oleh khalifah ayahnya, Kyai Ahmad Suhari Cibeber. ${ }^{18}$ Sepeninggal Syekh Asnawi, posisi pimpinan TQN di Banten diserahkan kepada keponakannya, Kyai Armin. Selain dua khalifah tersebut, Syekh Asnawi juga memiliki satu khalifah lagi yang menonjol, Syekh 'Abd al Latif bin Ali dari Cibeber. Awalnya, Syekh 'Abd al Latif menyebarkan TQN di

${ }^{15}$ Nicholas Tarling, ed, The Cambridge History of Southeast Asia Vol II: The Nineteenth and Twentieth Centuries (New York: Cambridge Press, 1992), 224.

16 Sartono Kartodirjo, Pemberontakan Petani Banten 1888 (Jakarta: Pustaka Jaya, 1984), 263-265.

17 Kharisudin Aqib, Al Hikmah, Memahami Teosofi Tarekat Qodariyah wa Naqsabandiyah, edisi revisi (Surabaya: Dunia Ilmu, 2000), 56.

18 Martin van Bruinessen, Tarekat Naqsyabandiyah di Indonesia (Bandung: Mizan, 1996), 94. 
Cibeber. Namun atas perintah Syekh Asnawi ia pindah ke Cilegon, dan menjadi khalifah gurunya di sana. Kemudian TQN di Cibeber diserahkan kepada Kyai Muhaimin. ${ }^{19}$

Selain Syekh Asnawi Caringin, Syekh Abdul Karim juga menunjuk beberapa khalifah lain di Jawa, di antaranya Syekh Ibrahim al Brumbungi Demak, Syekh Falak Pagentongan, ${ }^{20}$ dan Syekh Zarkasyi Berjan Purworejo. $^{21}$

\section{Syeikh Ahmad Thalhah}

Syekh Ahmad Thalhah adalah putra dari pengasuh Pondok Pesantren di kampung Tengah Taim (di sisi jalan utama yang menghubungkan Cirebon dan Bandung) dan tokoh Tarekat Syatariyyah, Kyai Tholabuddin. Nasab keluarganya sampai pada Sunan Gunung Jati dari putra pertamanya, Pangeran Trusmi. Oleh karena itulah Syekh Ahmad Tholhah mempunyai kedekatan dengan Sultan Kasepuhan X, Sultan Atmaja, bahkan menjadi salah satu penasehat pribadinya. ${ }^{22}$

Syekh Ahmad Thalhah, tahun pastinya tidak diketahui, menunaikan ibadah haji ke Mekah dan memperdalam keilmuan Islam, terutama Tarekat kepada Syekh Ahmad Khatib Sambas. Pada tahun 1876 M, ia pulang ke tanah air dan ditunjuk oleh Syekh Khatib sebagai khalifah-nya di daerah Cirebon dan sekitarnya. Selang tiga tahun dari kepulangannya (1879 $\mathrm{M})$, atas izin ayahnya ia mendirikan pondok pesantren TQN di Begong. Namun karena pondok tersebut hancur dilanda banjir ketika ditinggal ke Mekah yang kedua, dan situasi yang tidak menentu karena pemberontakan

${ }_{19}$ Sri Mulyati, et al, Mengenal dan Memahami Tarekat Tarekat Muktabarah di Indonesia, 263.

20 Martin van Bruinessen, "Shari'a Court, Tarekat and Pesantren: Religious Institutions in the Banten Sultanate", dalam Archipel, Vol. 50, (1995), 165-199. 122-125.

21 Amelia Fauzia, Faith and the State: A History of Islamic Philanthropy in Indonesia,

22 Sri Mulyati, et al, Mengenal dan Memahami Tarekat Tarekat Muktabarah di Indonesia, 267.

AL-A'RAF - Vol. XIII, No. 2, Juli - Desember 2016 
petani di Banten tahun $1888 \mathrm{M}$, kemudian ia pindah dan mendirikan pondok pesantren TQN baru di Trusmi. Dari pondok yang kedua inilah Syekh Ahmad Thalhah memiliki banyak murid yang datang dari pelbagai daerah. Di antara muridnya yang paling menonjol dan melanjutkan rantai kemursyidannya ialah Abdullah Mubarok bin Nur Muhammad (Abah Sepuh). Syekh Ahmad Thalhah meninggal tahun 1935 M, dan dimakamkan di dekat makam eyangnya, Sunan Gunung Jati, Cirebon. ${ }^{23}$

\section{Syeikh Ahmad Hasbullah Almaduri}

Biografi dan riwayat hidup Syeikh Ahmad Hasbullah tidak banyak diketahui. Data yang ada hanya menerangkan bahwa ia adalah putra Muhammad dari Madura, Jawa Timur. Ia belajar tarekat kepada Syekh Ahmad Khatib Sambas di Mekah, dan diangkat menjadi kbalifah-nya. Tidak diketahui pula bahwa selama atau selepas belajar kepada Syekh Ahmad Khatib ia pernah pulang ke Madura atau tidak, namun yang jelas ia lama berdomisili di Mekah dan wafat di sana. Ia mengangkat satu khalifah dari Jawa dan memerintahkan menyebarkannya di sana, yakni Kyai Muhammad Khalil dari Demak. ${ }^{24}$

\section{Syekhona Mubammad Kholil Bangkalan Almaduri}

Nama lengkapnya adalah Muhammad Kholil bin Abdul Latief bin Hamim bin Abdul Karim bin Muharom. Ia lahir pada 20 September 1834 M. dan wafat pada 24 April 1925 M. dalam usia 91 tahun. Ia dimakamkan di tanah kelahirannya, Desa Lagundih, Ujung Piring, Bangkalan, Madura. ${ }^{25}$

Syekhona Kholil, sebutan umumnya, disinyalir sebagai salah satu khalifah Syekh Ahmad Khatib Sambas. Pendapat ini didukung oleh Abah

${ }^{23}$ Sri Mulyati, et al, Mengenal dan Memahami Tarekat Tarekat Muktabarah di Indonesia, 267.

24 Sri Mulyati, Tasanuf Nusantara: Rangkaian Mutiara Sufi Terkemuka, 201.

25 Mahfudz Hadi, Berjuang Di Tengah Gelombang, Biografi dan Perjuangan Syaikhona Mohammad Kholil bin Abdul Latief Bangkalan Madura (Surabaya: eLKAF, 2010), 35. 
Anom, KH. As'ad Syamsul-Abdi Ndalem dan Santri kesayangan Syekhona Kholil-KH. M. Syafik Rofi'i, Kyai Hasbullah Muhtarom, Kyai Abdullah Mas'ud-ketiganya keturunan Syekhona Kholil, dan penelitian Unang Sunarjo. Pendapat berbeda diutarakan oleh dua keturunan Shekhona Kholil, yakni KH. Abdullah Schal dan KH. Khalil Yasin. ${ }^{26}$

Menurut Abdullah Schal dan Khalil Yasin, Syekhona Kholil berdiam diri tentang tarekat yang diikutinya, namun banyak ulama dan pemimpin tarekat Naqsyabandiyah dan TQN yang datang kepada Syekhona Kholil untuk meminta ijazah. ${ }^{27}$ Menurut penulis, pendapat Abdullah Schal ini tidak menyangkal pendapat pertama, tapi hanya menekankan bahwa Syekhona Kholil tidak tampak mempraktekkan dan mengajarkan TQN, namun memberikan ijazah kepada beberapa ulama yang sowan untuk meminta ijazah TQN. Salah satu ulama yang mendapatkan ijazah TQN dari Syekhona Kholil adalah 'Ali bin Umar bin Idrus bin Zain bin 'Alawi Bafaqih Ba 'Alawi Negara Bali. Sayid Ali bin Umar kemudian mengijazahkannya lagi kepada para muridnya, seperti Habib Muhammad Luthfi bin Ali Yahya Pekalongan. ${ }^{28}$ Salah satu majelis amalan TQN Habib Luthfi adalah Majelis MANISAN di Pekalongan. Majelis pengamalan dzikir TQN Habib Lutfi ini rutin dilaksanakan pada setiap Minggu Manis, dan dihadiri oleh ribuan orang yang mayoritas adalah ibu-ibu. ${ }^{29}$

Dalam penelitian Dhofier dan beberapa peneliti lain tidak memasukkan Syekhona Khalil sebagai salah satu khalifah Syekh Ahmad Khatib Sambas dan jalur utama sanad TQN di Jawa setidaknya ada dua dugaan alasan: pertama, karena Syekhona Kholil berdiam diri dan tidak

${ }_{26}$ M. Ali Haidar, "Tarekat Qodariyah wa Naqsabandiyah Syekhona Muhammad Kholil Bangkalan Tahun 1834-1925”, dalam Jurnal Avatara, Vol 1, No.2, Mei (2013), 8999. 260.

${ }^{27}$ Sri Mulyati, et al, Mengenal dan Memahami Tarekat Tarekat Muktabarah di Indonesia,

28 Wikipedia, "Muhammad Luthfi bin Yahya", https://id.wikipedia.org/wiki/ Muhammad_Luthfi_bin_Yahya, diakses pada tanggal 21 Mei 2016.

29 Wawancara via telepon dengan Husnul Marom (salah satu warga Pekalongan yang keluarganya merupakan partisan Majelis MANISAN) pada 22 Mei 2016. 
mengajarkan TQN sebagaimana diterangkan Abdullah Schal dan Khalil Yasin; kedua, seandainya Syekhona Kholil mengajarkan TQN, Dhofier tidak menemukan cabang TQN yang mengambil jalur darinya. Namun dengan melihat data di atas, dua alasan ini telah terbantahkan dan sudah semestinya Syekhona Kholil dimasukkan dalam deretan sanad utama TQN di Jawa.

\section{Pusat Penyebaran Tarekat Qadiriyab wa Naqsabandiyab di Jawa era 1970-an}

Pada era 1970-an, di Jawa terdapat sembilan pusat penyebaran TQN. Jika dipilah berdasar wilayah ialah: Jawa Barat terdapat dua pusat, yakni TQN Suryalaya dan TQN Pagentongan Bogor; Jawa Tengah terdapat tiga pusat, yakni: TQN Berjan Purworejo, TQN Mranggen, dan TQN As-Shalihiyah Dawe Kudus; dan Jawa Timur terdapat empat pusat, yakni: TQN Rejoso, TQN Cukir, TQN Al-Utsmaniyah Sawah Pulo, dan TQN Kencong Kediri. Lima pusat TQN penulis tambahkan pada hasil penelitian Dhofier, karena mereka adalah pusat TQN dengan mursyid mandiri dan memiliki jalur serta anggota tersendiri, sebagaimana dijelaskan di bawah ini.

\section{TQN Suryalaya Tasikmalaya}

TQN Suryalaya berpusat di Pondok Pesantren Suryalaya Godebag, atas rintisan $\mathrm{KH}$ Abdullah Mubarok. Abah Sepuh, sebutan KH Abdullah Mubarok, mendapatkan Khirqab (simbol penunjukkan sebagai mursyid) dari Syekh Ahmad Thalhah pada tahun 1908 M. Ketika berusia 116 tahun, Abah Sepuh menunjuk salah satu putranya, KH Shahibul Wafa Tajul Arifin (Abah Anom), yang berusia 35 tahun sebagai khalifah utamanya. Empat tahun kemudian, pada 25 Januari 1956, Abah Sepuh meninggal dunia dan kemursyidan dilanjutkan oleh Abah Anom. ${ }^{30}$

30 Sri Mulyati, et al, Mengenal dan Memahami Tarekat Tarekat Muktabarab di Indonesia, 
Pada masa kemursyidan Abah Anom, TQN Suryalaya berkembang pesat. Sejak awal diangkat sebagai mursyid hingga wafat pada tanggal 5 September 2011, Abah Anom mengangkat lebih dari 60 Wakil Talqin yang tersebar di Jawa, Madura, Lombok, Sumatra, Kalimantan, Sulawesi, bahkan Malaysia dan Singapura. Di antara Wakil Talqin Abah Anom di wilayah Jawa dan Madura, sesuai dengan fokus kajian ini ialah: Jawa Barat: KHR. Abdullah Syarif (alm.) di Ciawi Tasikmalaya, KH. Zaenal Abidin Anwar di Suryalaya, H. Sandisi di Suryalaya, K.H.A. Misbah Masduki (alm.) di Singaparna Tasikmalaya, K.H. Beben Muhammad Dabas di Pamijahan, K.H. Noor Anom Mubarok (alm.) di Bandung, Prof. Dr. H. A. Tafsir, MA. di Bandung, Prof. Dr. Juhaya S. Praja di Bandung, K.H. Arief Ichwanie AS di Bandung, K.H. Zezen Zainal Abidin Bazul Asyhab di Sukabumi, Muhsin Sanusi di Cobadak Sukabumi, H. Thohir Abdul Qohir di Danaraja Sumedang, H. Aah Zaenal Arifin di Ciranjang Cianjur, H. Asep Samsurizal Hudaya di Pamoyan Cianjur, H. Bahaudin Masruri (alm.) di Jati Cianjur, H. Miftahul Manan di Bojonglarang Cianjur, H. Iskandar Zulkarnaen di Kadupandak Cianjur, H. Otong Sidiq Djajawisastra (alm.) di Banjar Ciamis, KH. Abdul Rosyad (alm.) di Cikande Serang, H. Amin Abdullah di Pegantungan Cilegon, Kyai Kholil Sa’id di Ciomas Serang, K.H.R. A. Rohim Mahmud (alm.) Trusmi Wetan Cirebon, Kyai M. Sirojuddin Ruyani di Karawaci Tanggerang, dan K.H. Wahfiudin di Jakarta; Jawa Tengah: H. Nadori (alm.) di Bojong Tegal, K.H. Mohammad Busyaeri di Pangkah Tegal, K.H. Ahmad Jahri Anwar di Pekalongan, K.H. Anhari Basuki di Semarang, dan K.H. M. Thoha Abdurrahman di Depok Yogyakarta; dan, Jawa Timur [termasuk Madura]: K.H. Maliki Thohir di Sidoarjo, Kyai Muzakkia di Sidoarjo, H.M. Asrori Cholil (alm.) di Baureno Bojonegoro, K.H. Syaifullah di Leces Lumajang, K.H. Achmad Zuuhri di Benowo Surabaya, K.H.M. Ali Hanafiah Akbar di Sidotopo Surabaya, K.H. M. Helmy Basyaiban di Jatipuro Surabaya, dan selebihnya di Madura, yakni: 
K.H. Hasim Sanusi di Ganding Sumenep, H. Fadli Muntahi di Ambunten, H. Maimun Busthomi di Paragaan, serta H. A. Athorid Siraj di Pamekasan. Dengan melihat rentetan Wakil Talqin ini maka bisa dipahami bahwa mata rantai penyebaran TQN Suryalaya pada masa Abah Anom di wilayah Jawa dan Madura sangat kuat dan merata. ${ }^{31}$

Sepeninggal Abah Anom, kemursyidan TQN Suryalaya mengalami perselisihan. Sebagian besar wakil talqin dan keluarga dalem Abah Anom menyatakan bahwa kendatipun Abah Anom telah meninggal dunia, namun kemursyidan tetap diemban oleh beliau. Terkait pengelolaan Pondok Pesantren dan TQN Suryalaya, mereka menetapkan tiga orang sebagai pengemban amanat, yaitu: K.H. Noor Anom Mubarok, K.H. Zaenal Abidin Anwar, dan H. Dudun Noorsaiduddin. Hal ini didasarkan pada maklumat Abah Anom yang tidak menunjuk dan mengangkat mursyid setelahnya. $^{32}$

K.H. Muhammad Abdul Gaos Saefulloh Maslul, salah satu wakil talqin, tangan kanan dan yang dipasrahi Abah Anom mengelola Pesantren Inabah, ${ }^{33}$ kendatipun tanpa penunjukkan dan restu keluarga Abah Anom menyatakan diri sebagai mursyid TQN Suryalaya sepeninggal beliau. Pengakuan Abah Gaos (sapaannya), ini ditentang oleh mayoritas wakil talqin, pemangku amanat, dan keluarga Abah Anom karena memang Abah Anom tidak pernah menunjuk mursyid setelahnya. Kemudian berdasarkan hasil musyawarah seluruh wakil talqin yang dilaksanakan bersamaan dengan peringatan 40 hari wafatnya Abah Anom, Abah Gaos dan pendukungnya KH. Muhammad Sholeh dikeluarkan dari anggota wakil talqin TQN

31 Daftar hadir wakil talqin dalam lampiran Surat Keputusan Ijma' Wakil Talqin TQN PP Suryalaya dan Ahli Waris Syekh Mursyid KH. Ahmad Shohibul Wafa' Tajul Arifin Ra pada peringatan 40 hari wafatnya Abah Anom, 2013.

32 Sambutan KH. Wahfiudin dalam acara Khidmat Ilmiah Manaqib di Pon. Pes. Suryalaya pada tanggal 23 Januari 2013.

33 Rido Kurnianto, "Kajian Makna Simbol Kupu-Kupu Terbang Ke Langit Pada Tarekat Qadiriyah Naqshabandiyah Suryalaya Tasikmalaya”. Marajï: Jurnal Studi Keislaman. Vol. 2. No. 2. Maret (2016), 382-399. 
Suryalaya. ${ }^{34}$

Kendatipun demikian, Abah Gaos tetap kukuh dengan pendiriannya dan mengangkat banyak khalifah. Dalam jangka waktu tiga bulan (OktoberDesember 2013), Abah Gaos sudah menunjuk 31 orang khalifah. Pada tanggal 14 Oktober 2013 menunjuk 9 orang khalifah, yaitu: K.H. Mustofa Jedah Arab Saudi, K.H. Masqi Banten, Prof. Dr. K.H. Asep Usman Ismail Jakarta, K.H. Jujun Junaedi Bandung, K.H. Ubaidillah Ambarawa, K.H. Dadang Muliawan Panjalu Ciamis, K.H. As'ad Palembang, K.H. Ali Asyiq Masruri Bekasi, dan K.H. Ayi Burhanudin Pelabuhan Ratu, Sukabumi; tanggal 14 November 2013 menunjuk 10 orang khalifah, yaitu: Prof. K.H. Nasarudin Umar Jakarta, K.H. Abdulloh Munif Pasuruan, K.H. Iqro' Abdurro'uf Lampung, K.H. M. Hasan Bangkalan Madura, K.H. Irfan Zidni DKI Jakarta, K.H. Syafi'i Abrori Purbalingga, K.H. Syamsul Bahri Pasuruan, K.H. Rofiqul Khoir Malang, K.H. Anshori Selangor Malaysia, dan K.H. Ahmad Jalaludin Majenang; dan tanggal 12 Desember 2013 menunjuk 11 orang khalifah, yaitu: K.H. Saefuddin Hamzah Banjarnegara, K.H. Asep Tanjungjaya, Singparna, Tasikmalaya, K.H. Jajang Arum Tasikmalaya, K.H. Dede Banjar Ciamis, K.H. Adnan Banten, K.H. Akbar Bogor, K.H. Reda Matovani DKI Jakarta, K.H. Hasan Bandung, K.H. Yusuf Cirebon, K.H. Sahid Arifin Majalengka, dan terakhir Dr. Ari Ginanjar Sebastian pemilik ESQ DKI Jakarta. ${ }^{35}$

\section{TQN Pagentongan Bogor}

TQN Pagentongan berpusat di Pondok Pesantren al-Falak Pagentongan di bawah asuhan Tubagus Muhammad Falak (1842-1972). Mama Falak, sebutan masyarakat sekitar, adalah putra tunggal pengasuh Pondok Pesantren Sabi Pandeglang, Kyai Tubagus Abbas bin Mu'min

34 Surat Keputusan Ijma' Wakil Talqin TQN PP Suryalaya dan Ahli Waris Syekh Mursyid KH. Ahmad Shohibul Wafa' Tajul Arifin Ra”, 2013.

35 Mahmud Jonsen, "Daftar Wakil Talqin TQN PPS”, http://mahmudjonsen. blogspot.co.id. Diakses pada tanggal 12 April 2016. 
Abdul Hamid. Pada tahun 1857, Mama Falak berangkat ke Mekah guna menunaikan haji dan memperdalam keilmuan Islam. Atas anjuran Syekh Sohib Kadu Pinang, salah satu gurunya ketika masih di Banten, selama di Mekah ia tinggal di rumah Syekh Abdul Karim Banten dan belajar TQN kepadanya hingga diangkat menjadi salah satu khalifah. ${ }^{36}$

Pada tahun 1878, Mama Falak pulang ke Nusantara dan menyebarkan TQN di tanah kelahirannya. Namun karena situasi pasca pemberontakan petani 1888 , dan ia ikut aktif di dalamnya, ${ }^{37}$ empat tahun kemudian ia kembali ke Mekah. Masa kepergian yang keduanya ini, Mama Falak semasa dengan KH. Hasyim Asy'ari dan K.H. Ahmad Dahlan. Pada awal abad ke-20 M, Mama Falak pulang ke Nusantara, dan mendirikan Pondok Pesantren al-Falak di Pagentongan Bogor pada tahun 1907. ${ }^{38}$ Karena kealiman dan kemasyhuran Mama Falak, pondok pesantren asuhannya menjadi salah satu tujuan belajar para santri dan menjelma menjadi salah satu pusat penyebaran TQN di Nusantara. Namun setelah Mama Falak wafat, lambat laun pamor Pondok Pesantren al-Falak meredup. Kendatipun demikian, pengajaran TQN masih dilanjutkan oleh putranya, Kyai Tubagus Muhammad Tohir Falak, hingga sekarang. ${ }^{39}$

\section{TQN Mranggen Demak}

TQN Mranggen berpusat di Pondok Pesantren Alfutuhiyah Mranggen, Demak di bawah asuhan al-Mursyid K.H. Muslih Abdurrahman. K.H. Muslih mulai belajar TQN dari ayahnya, K.H. Abdurrahman bin Qoshidil Haq Subur, kemudian melanjutkan kepada guru ayahnya, Syekh Ibrahim Albrumbungi. Sebelum ia mendapatkan Ijazah Irsyad, Syekh Ibrahim pun wafat. K.H. Muslih pun melanjutkan dan mendapat ijazah

${ }^{36}$ Nina H Lubis, dkk, Sejarah Perkembangan Islam di Jawa Barat (Tkp:Tp, tt), 99-100.

37 Sartono Kartodirjo, Pemberontakan Petani Banten 1888 (Jakarta: Pustaka Jaya, 1984), 263-265.

38 Nina H Lubis, dkk, Sejarah Perkembangan Islam di Jawa Barat, 55.

39 Sri Mulyati, et al, Mengenal dan Memahami Tarekat Tarekat Muktabarah di Indonesia, 263. 
Irsyad dari khalifah Syekh Ibrahim serta teman satu angkatan ayahnya, K.H. Abdurrahman Menur. Selain itu, K.H. Muslih juga berbai'at kepada dan mendapatkan ïazah Irsyad dari Syekh 'Abd Latif bin Ali, salah satu khalifah dari khalifah Syekh Abdul Karim di Banten, Syekh Asnawi Caringin, Banten. Dengan demikian, pada diri K.H. Muslih Abdurrahman bertemu dua jalur sanad dari dua khalifah Syekh Abdul Karim, yakni: Syekh Ibrahim Albrumbungi melalui K.H. Abdurrahman Menur, dan Syekh Asnawi Caringin melalui Syekh 'Abd Latif bin Ali. ${ }^{40}$

Selain ayah K.H. Muslih dan K.H. Abdurrahman Menur, Syekh Ibrahim juga memiliki satu khalifah lagi yang menonjol, yaitu K.H. Hasan Anwar Gubuk. K.H. Hasan Anwar menyebarkan TQN di Gubuk yang dilanjutkan oleh Kyai Madchan di Purwodadi (w. 1977), lalu oleh putranya, K.H. Ahmad Qomaruddin Madchan (w. 2001), dan sekarang oleh Kyai Ahmad Mujahiddin Madchan. ${ }^{41}$

K.H. Muslih mengajarkan TQN di Mranggen sejak awal tahun 1950-an hingga ia wafat saat melaksanakan ibadah Haji tahun 1981. Karena kedua putranya saat itu masih dianggap terlalu muda untuk menggantikannya, pengajaran TQN Mranggen pun untuk sementara waktu dipegang oleh adik dan menantunya, yakni: K.H. Ahmad Muthohar (w. 2007), K.H. Makhdum Zain, K.H. Ridhwan Kholilur Rahman, dan K.H. Abdurrahman. ${ }^{42}$ Kendatipun demikian, menurut Mulyati pelanjut kemursyidan K.H. Muslih adalah KH Muhammad Luthfil Hakim Muslih yang kemudian sepeninggalnya dilanjutkan oleh adiknya, K.H. Muhammad Hanif Muslih hingga sekarang. Selain orang-orang ini, K.H. Muslih juga mengangkat beberapa mursyid mandiri atau khalifah lain, diantaranya ialah:

40 Ahmad Aziz Masyhuri, Ensiklopedi 22 Aliran Tarekat dalam Tasawnf (Surabaya: Imtiyaz, 2011), 199.

41 Tim PP an-Nawawi, Mengenal KH. Nawawi Berjan Pumvorejo (Surabaya: Khalista, 2008), 96-107.

42 Martin van Bruinessen, "Muslih b. 'Abd al-Rahman al-Maraqi", dalam Dictionnaire Biographique des Savamts et Grandes du Monde Musulman Peripherique, du XIXe Siecle a Nos Jours, Fasc., No. 2, Paris: CNRS-EHESS, (1998), 23-24. 
K.H. Abu Nur Jazuli Brebes, K.H. Duri Nawawi Kajen Pati, K.H. Adlan Aly Cukir Jombang, K.H. Zamroji Pare, Kediri, K.H. Muhammad Shiddiq Piji Kudus, dan lain sebagainya. ${ }^{43}$

Di bawah K.H. Muhammad Hanif Muslih, anggota TQN Mranggen yang dulunya tercecer (tidak terorganisir), berkat dibentuknya wadah bernama Majelis Thariqah Qadiriyah wa Naqsyabandiyah Mranggen semakin berkembang. Sekarang, anggota TQN Mranggen tidak kurang dari lima puluh ribu orang. Dilihat dari beberapa nama yang tercantum dalam daftar pengurus pusat, tersebar di beberapa kota di Jawa Tengah (Demak, Ungaran, Grobogan, Kendal, Brebes, Wonosobo), Jawa Timur (Malang dan Mojokerto), Banjar Jawa Barat, Lampung, Samarinda, dan Pontianak. ${ }^{44}$

\section{TQN Berjan Purworejo}

TQN Berjan berpusat di Pondok Pesantren Mafatihul Ulum Berjan, Gintungan, Gebang, Purworejo, sekarang berganti nama PP Alnawawi. Pesantren TQN ini didirikan oleh Syekh Zarkasyi (w. 1917) pada tahun 1870 atas perintah gurunya pasca pulang dari Mekah, Syeikh Soleh Darat Semarang. Ketika di Mekah, tidak diketahui kapan berangkat dan pulangnya, selain melaksanakan ibadah haji, ia menetap beberapa lama untuk memperdalam keilmuan Islam. Dalam ilmu Tarekat ia belajar kepada Syekh Abdul Karim Banten, dan mendapatkan ijazah kemursyidan darinya. Sepeninggal Syekh Zarkasyi, pengajaran TQN di Berjan dilanjutkan oleh putranya, K.H. Muhammad Shiddiq (w. 1948), kemudian K.H. Muhammad Nawawi (w. 1982), dan sekarang dilanjutkan oleh K.H. Chalwani Nawawi. ${ }^{45}$ Pada masa Syekh Zarkasyi, TQN Berjan menyebar ke daerah sekitarnya dan beberapa wilayah lain seperti Magelang, Temanggung, Salatiga, dan

\footnotetext{
43 Sri Mulyati, Tasawnf Nusantara: Rangkaian Mutiara Sufi Terkemuka, 184-186.

44 Daftar nama dalam susuna Pengurus Pusat Majelis Thariqah Qadiriyah wa Naqsyabandiyah Mranggen, Demak, Jawa Tengah, Periode 2013-2018.

45 Amelia Fauzia, Faith and the State: A History of Islamic Philanthropy in Indonesia (Leiden: Brill, 2013), 122-125.
} 
bahkan ke Malaysia. Di Magelang, Temanggung, dan Salatiga disebarkan oleh dua orang khalifah utamanya, yaitu Syekh Umar Payaman Magelang dan saudara K.H. Dalhar Watucongol, Syekh Mudzakir. Sedangkan di Malaysia disebarkan oleh Syekh Siraj. ${ }^{46}$ Di antara murid terkemuka Syekh Umar Payaman ialah Syekh Muhammad 'Ali. Ia mendirikan Pondok Pesantren TQN Roudlotuth Tholibin di Sempu, Secang, Magelang, dan sekarang dilanjutkan oleh putranya K.H. Ismail 'Ali. Dari pesantren ini TQN Berjan, di antaranya menyebar ke Madiun melalui K.H.R Izzuddin (w. 1979) dan kemudian ke Tegalarum, Pelem, Kertosono, Nganjuk melalui K.H. M. Munawir Musthofa (w. 2001). ${ }^{47}$

Menurut penuturan pengasuh TQN di Berjan sekarang, K.H. A. Chalnawi Nawawi, pada masa K.H. Muhammad Shiddiq TQN Berjan juga menyebar ke Jember yang dibawa oleh salah satu murid utamanya, Syekh Haramain; dan menyebar pesat di Jambi yang dibawa oleh salah satu muridnya, Syekh Ali bin Abdul Wahhab Tungkal, dan sekarang muridnya sekitar 500.000 orang. ${ }^{48}$

\section{TQN As-Shalibiyah Dawe Kudus}

TQN As-Shalihiyah berpusat di Pondok Pesantren Manba'ul Falah, Piji, Dawe, Kudus. Pusat TQN ini didirikan oleh Almursyid K.H. Muhammad Shiddiq as-Sholihi pada tahun 1974. Awalnya, K.H. Shiddiq adalah khalifah K.H. Musta’in Romly di Piji. ${ }^{49}$ Namun karena alasan jarak,

46 Achmad Chalwani Nawawi, "Mengenal Tarekat di Berjan Purworejo", disampaikan pada audiensi dalam rangka penelitian mahasiswa UI Jakarta di PP an Nawawi Berjan, 08 Juni 2008.

${ }^{47}$ M. Misbahul Ulum, "Biografi KHM Munawwir Musthofa al-Mursyid”, http:/ / kol-il.blogspot.co.id/2015/02/biografi-kh-m-munawwir-musthofa-al.html, diakses pada tanggal 26 Mei 2016.

48 Achmad Chalwani Nawawi, "Mengenal Tarekat di Berjan Purworejo", disampaikan pada audiensi dalam rangka penelitian mahasiswa UI Jakarta di PP an Nawawi Berjan, 08 Juni 2008.

49 Asfa Widiyanto, “'Manaqib Writing in The Circle of The Tariqa Qadiriyya wa Naqsyabandiyyah: A Study on Muhammad Siddiq al-Salihi's Nayl al-Amani”, Heritage of Nusantara. Vol. 4. No. 2. Desember (2015), 213-242. 
finansial, dan perbedaan aliansi partai politik (K.H. Musta'in Romly Golkar dan K.H. Muhammad Shiddiq PPP), dengan ditemani dua teman satu angkatannya, Mudatsir dan Abdurrahman, ia menghadap kepada Syekh Muslih Mranggen untuk meminta ijazah irsyad mandiri dan dikabulkan. Atas dasar ini kemudian ia mendeklarasikan kemursyidannya dan terpisah dari TQN Rejoso. Menurut sumber lain, K.H. Shiddiq kemudian juga mendapatkan ijazah irsyad mandiri dari KH Musta'in Romly, yakni pada tahun $1983 .{ }^{50}$

Anggota TQN As-Shalihiyah makin lama makin bertambah banyak. Pada waktu pendeklarasian, jumlah anggotanya sekitar 200 orang, tahun 1978 berjumlah 900 orang, dan tahun 1988 berjumlah 2500 orang. Mereka tidak hanya dari Kudus, namun juga dari Pati, Jepara, Demak, Rembang, Blora, dan beberapa kota di Jawa Timur. Oleh karena itu, maka K.H. Shiddiq menunjuk delapan khalifah untuk membantunya, di antaranya yaitu: K.H. Ilyas Mansur di daerah Piji Barat, K.H. Nasihun di Samirejo, K.H. Ali Muhyidin di Samirejo Selatan, K.H. Nasuha di Piji Tengah, K.H. Syahid di Jurang, K.H. Hayatun di Lau Barat, dan K.H. Abdul Azis di Lau timur. Dengan diangkatnya delapan khalifah ini, tahun 1990 jumlah anggota meningkat menjadi 5000 orang, tahun 2000 meningkat menjadi 6000 orang, dan tahun 2011 berjumlah 10.000 orang. Pada tahun 2011, untuk memperluas TQN As-Shalihiyah di luar Kudus, K.H. Shiddiq membuka cabang dan mengangkat badal Mursyid di beberapa daerah, yaitu: K.H. Asnawi di Sumur Watu Pasuruan, K.H. Noor Jusno di Pati, K.H. Affandi di Tuban, dan K.H. Mohammad Shodiq di Jakarta. ${ }^{51}$

Sepeninggal K.H. Shiddiq (w. 2009), kemursyidan TQN AsShalihiyah dilanjutkan oleh dua putranya, K.H. Abdul Lathif Shiddiq dan K.H. Affandi Shiddiq, dengan dibantu oleh satu khalifah, yakni Kyai

${ }^{50}$ Ma'mun Mu'min, “Sejarah Tarekat Qodiriyah wan Naqsabandiyah Piji Kudus”, Fikrah. Vol. 2. No. 1. Juni (2014), 357-377.

51 Ma'mun Mu'min, “Sejarah Tarekat Qodiiriyah wan Naqsabandiyah Piji Kudus”, Fikrah. Vol. 2. No. 1. Juni (2014). 357-377. 
Muhtar Amin Shiddiq. ${ }^{52}$

\section{TQN Rejoso Jombang}

TQN Rejoso berpusat di Pondok Pesantren Darul Ulum Rejoso Jombang. TQN di Rejoso ini bukan dibawa oleh pendiri Pondok Pesantrennya, Kyai Tamim Irsyad, namun oleh menantunya yaitu Kyai Muhammad Khalil. Juroimi, nama kecil Kyai Muhammad Khalil, adalah santri Kyai Tamim Irsyad yang pada awal abad ke 20 M pergi ke Mekah untuk ibadah haji dan berguru TQN kepada Syekh Ahmad Hasbullah alMaduri hingga akhirnya mendapatkan ijazah irsyad darinya. ${ }^{53}$

Kyai Muhammad Khalil meninggal tahun 1937, dan sebelum itu ia telah menyerahkan kemursyidan kepada adik iparnya, K.H. Romly Tamim (w. 1957). Sepeninggal Kyai Romly, secara berurutan, kemursyidan dilanjutkan oleh K.H. Musta'in Romly (w.1985), K.H. Rifa'i Romly (w.1994), dan K.H. Dimyati Romly. ${ }^{54}$ Menurut Endang Turmudi, K.H. Dimyati Romly tidak mendapatkan ijazah irsyad langsung dari ayah maupun kakaknya, namun mendapatkannya dari K.H. Ma’sum, salah satu wakil mursyid K.H. Romly Tamim dan K.H. Musta'in Romly. ${ }^{55}$ Sepeninggal K.H. Dimyati Romly (18 Mei 2016), belum ditemukan data siapa penerus kemursyidannya.

Pada masa kemursyidannya, K.H. Romly Tamim memiliki beberapa murid dan khalifah utama, di antaranya ialah: K.H. Muhammad Abbas Buntet Cirebon, K.H. Muhammad Usman al-Ishaqi Sawah Pulo Surabaya, K.H. Ahmad Shonhaji Kebumen, Jawa Tengah, K.H. Muhammad Shiddiq

52 Danusiri, "Menumbuhkan Potensi Beragama Kaum Tarekat Qadiriyah wa Naqsyabandiyah Dawe Kudus", Analisa, Vol.19, No. 01, Januari-Juni (2012), 27-36, dan Ma'mun Mu'min, "Sejarah Tarekat Qodiriyah wa Naqsabandiyah Piji Kudus", Fikrah. Vol. 2. No. 1. Juni (2014), 357-377..

53 Sri Mulyati, Tasanuf Nusantara: Rangkaian Mutiara Sufi Terkemuka, 201.

54 R. Ahmad Maduki Rif'at, "Pemikiran KH. Achmad Asrori al-Ishaqy", Sinopsis Tesis (Semarang: UIN Walisongo, 2011), 12.

55 Endang Turmudi, Struggling for the Ulama: Changing Leadership Roles of Kiai in Jombang, East Java (ANU: E Press, 2006), 84-85. 
Dawe Kudus, K.H. Adlan Ali Cukir Jombang, K.H. Imron Hamzah Surabaya, K.H. Shobiburrohman Jepara, K.H. Musta'in Romly Rejoso, Kyai Maki Karangkates Mojo Kediri, Kyai Ja'far Karangkates Mojo Kediri, K.H. Mansur Anwar Paculgowang Jombang, Kyai Muhdar Rejoso Jombang $^{56}$, KH. Ma'sum Tanggulangin Sidoarjo ${ }^{57}$ dan KH. Zamrodji Kencong Pare Kediri. ${ }^{58}$

Pada saat kemursyidan dipegang oleh K.H. Musta'in Romly, semua khalifah ayahnya berbaiat setia kepada K.H. Musta'in Romly. Bahkan, di bawah pimpinan K.H. Musta'in Romly TQN Rejoso berkembang pesat. Terlebih lagi setelah ia ditunjuk untuk menjadi ketua umum Jam’iyyah Ahli Thariqah al-Mu'tabarah pada tahun $1975 .{ }^{59}$ Namun tidak lama kemudian, karena memutuskan untuk mendukung Golkar, partai politik yang berbeda dengan partai mayoritas kaum Nahdliyin (pemilu 1977), pamor K.H. Musta'in Romly menurun drastis dan banyak khalifah utamanya memisahkan diri dari TQN Rejoso. Mereka ialah: K.H. Adlin Ali Cukir, K.H. Usman al-Ishaqi Sawah Pulo, K.H. Muhammad Siddiq Dawe Kudus, dan K.H. Zamrodji Kencong.

\section{TQN Al-Utsmaniyah Sawah Pulo Surabaya}

TQN Al-Uthmaniyah berpusat di Pondok Pesantren Sawah Pulo Surabaya di bawah asuhan al-Mursyid KH. Muhammad Uthman al-Ishaqi al-Nadi. Sepeninggalnya tahun 1984, kemursyidan dilanjutkan putranya, K.H. Achmad Asrori al-Ishaqi, dan memindah pusat TQN Al-Uthmaniyah 112-114.

56 Zulkifli, Sufism in Java: The Role of Pesantren in The Maintenance of Sufism in Java,

57 Sri Mulyati, et al, Mengenal dan Memahami Tarekat Tarekat Muktabarah di Indonesia, 262.

58 Endang Turmudi, Struggling for the Ulama: Changing Leadership Roles of Kiai in Jombang, East Java, 108.

59 Zulkifli, Sufism in Java: The Role of Pesantren in The Maintenance of Sufism in Java, 114.

AL-A'RAF - Vol. XIII, No. 2, Juli - Desember 2016 
ke Pondok Pesantren al-Fitrah di Kedinding Lor Surabaya. ${ }^{60}$

K.H. Uthman adalah salah satu khalifah utama K.H. Romly Tamim dan mendapatkan ijazah irsyad darinya. Bahkan menurut sebuah sumber, KH. Musta'in Romly mendapatkan ijazah irsyad dari K.H. Uthman. Sebab K.H. Musta'in Romly belum mendapatkannya dari ayahnya, K.H. Romly Tamim. ${ }^{61}$ Awalnya, TQN Al-Uthmaniyah merupakan cabang dari TQN Rejoso, namun setelah K.H. Romly Tamim wafat dan K.H. Musta'in Romly tidak memasukkan dirinya dalam jalur sanad TQN-nya, K.H. Uthman memisahkan diri dari TQN Rejoso dan berdiri sendiri.

Jauh sebelum wafat (1978) K.H. Uthman al-Ishaqi telah memilih salah satu putranya, K.H. Achmad Asrori al-Ishaqi, sebagai penggantinya. Namun sebelum ayahandanya wafat, K.H. Achmad Asrori tidak mau bertindak sebagai mursyid. Baru setelah itu, ia bertindak sebagai mursyid dan memindahkannya ke Pesantren yang didirikan, Pesantren al-Fitrah di Kedinding Lor Surabaya. ${ }^{62}$

Berkat kharisma dan kreatifitas K.H. Achmad Asrori al-Ishaqi, TQN al-Uthmaniyah berkembang dengan pesat. Anggotanya tidak hanya tersebar di Jawa dan Madura, namun juga ke mancanegara, seperti Singapura, Malaysia, Brunei Darussalam, Thailand, bahkan Arab Saudi dan Australia. Di antara media yang digunakan oleh K.H. Achmad Asrori untuk memperkenalkan TQN kepada masyarakat umum melalui Jam'iyyah al-Khidmah, sebuah jam'iyyah yang di dalamnya dibacakan maulid diba'iyyah, manaqib syekh Abdul Qadir al-Jailani, shalawat, beberapa untaian rikir, dan sesekali diiringi dengan rebana serta terdapat tausyiyah yang sangat menyentuh dan menyejukkan hati dari K.H. Achmad Asrori atau

${ }^{60}$ R. Ahmad Maduki Rif'at, "Pemikiran KH. Achmad Asrori al-Ishaqy", Sinopsis Tesis (Semarang: UIN Walisongo, 2011), 13.

${ }^{61}$ Martin Van Bruinessen, Tarekat Naqshabandiyah di Indonesia, 96.

62 R. Ahmad Maduki Rif'at, "Pemikiran KH. Achmad Asrori al-Ishaqy", Sinopsis Tesis (Semarang: UIN Walisongo, 2011), 13. 
yang mewakilinya. ${ }^{63}$ Jam'iyyah al-Khidmah ini dilakukan secara berkeliling antar kota atau antar pondok pesantren. Di antara Pondok Pesantren yang setiap tahun selalu menyelenggarakannya, ialah Pondok Pesantren al-Fitrah Kedinding Lor Surabaya, Pondok Pesantren Lirboyo Kediri, Pondok Pesantren Kyai Makki Karangkates Kediri, Pondok Pesantren alIshlahiyyah Kemayan Mojo Kediri.

Pada tanggal 26 Sya’ban 1430 Hijriyah (18 Agustus 2009 M.), K.H. Achmad Asrori al-Ishaqi wafat dengan usia 52 tahun. Sebelum wafat, K.H. Achmad Asrori tidak menunjuk atau memberikan petunjuk penggantinya, sehingga sampai tulisan ini di tulis belum ada mursyid pengganti beliau. Data yang penulis dapatkan dari beberapa nara sumber bahwa TQN alUthmaniyah berjalan di bawah bimbingan para Imam khususiyah yang dulu ditunjuk oleh K.H. Achmad Asrori. ${ }^{64}$

\section{TQN Cukir Jombang}

TQN Cukir awalnya berpusat di Pondok Pesantren Tebuireng, namun karena beberapa hal kemudian pindah di Masjid Jami' Cukir hingga sekarang. Mursyid pertama TQN Cukir adalah K.H. Adlan Ali, pendiri Pondok Pesantren Putri Walisongo Cukir. Awalnya, K.H. Adlan Aly adalah khalifah TQN Rejoso di bawah mursyid K.H. Romly Tamim dan KH Musta'in Romly. ${ }^{65}$ Karena keputusan kontroversial K.H. Musta'in Romly yang mendukung Golkar, atas perintah K.H. Hasyim Asy'ari dan dukungan mayoritas ulama Nahdliyin, TQN Cukir berdiri sendiri dan ia ditunjuk sebagai mursyidnya. Guna memenuhi syarat kemursyidan, karena belum memiliki ijazah irsyad, K.H. Adlan Aly meminta ijazah irsyad kepada Syekh Muslih Mranggen dan dikabulkan. Setelah kemursyidan, pengikut

${ }_{63}$ R. Ahmad Maduki Rif’at, "Pemikiran KH. Achmad Asrori al-Ishaqy", Sinopsis Tesis (Semarang: UIN Walisongo, 2011), 13.

64 Wawancara via telepon dengan Ahmad Badi' dan Ahmad Zaenuri (Abdi dari salah satu pimpinan Al-Khidmah TQN al-Utsmaniyah Kediri) pada tanggal 22 Mei 2016.

65 Zamakhsyari Dhofier, Tradisi Pesantren: Studi tentang Pandangan Hidup Kiai (Jakarta: LP3ES, 1985), 12. 
K.H. Adlan Aly yang dulu ketika menjadi khalifah K.H. Musta'in Romly hanya 52 orang, pada bulan November 1977 pengikutnya meningkat hingga 1500 orang. ${ }^{66}$

Hal yang perlu diketengahkan di sini adalah kepemimpinan TQN Cukir dalam satu masa selalu diisi oleh dua orang, satu sebagai mursyid dan lainnya sebagai wakil mursyid. Jika mursyid telah wafat, maka wakilnya akan menggantikan posisinya dan memilih wakil baru. Pada masa kemursyidan K.H. Adlan Aly, ia mengangkat K.H. Makki Ma’sum sebagai wakilnya. K.H. Adlan Aly wafat tahun 1990, K.H. Makki Ma’sum naik posisi sebagai mursyid dan menunjuk wakil Kyai Sholihin Hamzah. K.H. Makki Ma'sum wafat tahun 2002, Kyai Sholihin naik sebagai mursyid dan menunjuk wakil K.H. Rifa'i. Karena pada awal tahun 2006 K.H. Rifa'i meninggal mendahului Kyai Sholihin, maka posisi wakil digantikan oleh putranya, K.H. Shalahuddin Rifa'i. Kemudian sepeninggal Kyai Sholihin (akhir tahun 2006), posisi mursyid digantikan oleh K.H. Shalahuddin Rifa’i dan mengangkat wakil K.H. Maftuh Makki pada tahun 2007. Dengan demikian, maka TQN Cukir sekarang dipimpin oleh pemimpin generasi keempat. $^{67}$

Menurut K.H. Maftuh Makki, sebagaimana dikutip Zuhdi, sampai sekarang Cukir, tepatnya di Masjid Jami' Cukir, masih dijadikan sebagai lokasi pusat penyebaran TQN Cukir. Tambahnya lagi, pada tahun 2011 jumlah anggota TQN Cukir lebih dari seratus ribu orang yang tersebar di Madura, Jawa Barat, Jakarta, Lampung, Kalimantan Tengah, Kalimantan Utara, Kalimantan Timur, Riau, dan beberapa wilayah Indonesia lainnya. ${ }^{68}$

${ }^{66}$ Zulkifli, Sufism in Java: The Role of Pesantren in The Maintenance of Sufism in Java, $112-114$.

${ }^{67}$ Zaenu Zuhdi, "Ibadah Penganut Tarekat: Studi Tentang Afiliasi Madhab Fikih Tarekat Qadiriyah wa Naqshabandiyah, Shiddiqiyyah dan Shadhiliyah di Jombang", Disertasi (Surabaya: UIN Sunan Ampel 2013), 99-100.

${ }^{68}$ Zaenu Zuhdi, "Ibadah Penganut Tarekat: Studi Tentang Afiliasi Madhab Fikih Tarekat Qadiriyah wa Naqshabandiyah, Shiddiqiyyah dan Shadhiliyah di Jombang", Disertasi (Surabaya: UIN Sunan Ampel 2013, 99-100. 


\section{TQN Kencong Kediri}

TQN Kencong berpusat di Pondok Pesantren Raudlatul Ulum dengan mursyid K.H. Zamrodji. Awalnya, K.H Zamrodji adalah salah satu badal K.H. Romly Tamim dan K.H. Musta'in Romly di Kencong, Pare, Kediri. Ia memulai belajar TQN kepada K.H. Romly Tamim sekitar tahun 1950-an, setelah ia menamatkan belajarnya di Pondok Pesantren Lirboyo Kediri. Tidak berselang lama, K.H. Romly Tamim menyuruh K.H. Zamrodji pulang ke Kencong dan mencari teman untuk masuk TQN. Dengan bantuan temannya, Khoiri dan Mbah Mahalli, tetua Dusun Nongkorejo Pare, K.H. Zamrodji mendapatkan 17 orang untuk dibai'at. Setelah itu, K.H. Zamrodji memberitahukannya kepada K.H. Romly Tamim dan datanglah K.H. Romly Tamim ke Kencong untuk membai'at dan memerintahkan mereka untuk melakukan khususiyah beberapa hari kemudian. Pembai'atan ini dilakukan pada Rebo Legi, bulan Dzulhijjah, tahun 1952 M. dan khususiyah yang diperintahkan ialah pada hari Sabtu Wage setelahnya. Atas dasar ini, hingga sekarang TQN Kencong mengadakan bai'atan dan khususiyah selapan sekali pada hari Sabtu Wage, ithba' dengan perintah K.H. Romly Tamim di awal diadakannya pembai'atan dan khususiyah di Kencong. ${ }^{69}$

Sebagaimana cabang-cabang TQN Rejoso lainnya, TQN Kencong juga kena imbas dari konflik politik K.H. Musta'in Romly menjelang pemilu 1977. K.H. Zamrodji kemudian mengutus Mbah Mahalli menghadap K.H. Adlan Ali untuk menyatakan sumpah kesetiaan K.H. Zamrodji kepada beliau, namun K.H. Adlan Ali menolaknya dan mengatakan supaya K.H. Zamrodji menjadi mursyid yang berdiri sendiri. Awalnya K.H. Zamrodji gamang, namun karena mendapat dukungan oleh seluruh Kyai Kediri yang dikumpulkan dan dipimpin oleh K.H. Mahrus Aly Lirboyo Kediri, K.H. Zamrodji menerimanya. Karena K.H. Zamrodji belum mendapatkan

${ }^{69}$ Roudlatul Ulum, "Profil Singkat KH. Zamrodji al-Mursyid Pendiri PP Raudlatul Ulum Kencong”, http://raudlatululumkencong.blogspot.co.id/2014/03/ kajian-thoriqoh-qodiriyah-wa.html. diakses pada tanggal 12 April 2016. 
ijazah irsyad, baik dari K.H. Romly Tamim maupun K.H. Musta'in Romly, pertemuan para kyai tersebut menyuruh K.H. Zamrodji dengan ditemani K.H. Jupri Karangkates Mojo Kediri (juga salah satu khalifah K.H. Romly Tamim) dan Syafi'i Sulaiman dari Bangsongan Kediri untuk meminta ijazah irsyad kepada Syekh Muslih Mranggen, dan dikabulkan. Dengan ini, K.H. Zamrodji sudah sah menjadi mursyid mandiri TQN di Kencong Kediri. Anggotanya adalah orang-orang di sekitar Kediri dan santri-santri Pondok Pesantren Roudlatul Ulum. K.H. Zamrodji wafat pada tanggal 11 September 1999 dan kepemimpinan TQN Kencong diserahkan kepada putranya yang memimpin hingga sekarang, K.H. Muhammad Nuril Anwar. $^{70}$

\section{Penutup}

Dari ulasan di atas, bisa disimpulkan bahwa TQN masuk ke Jawa pada akhir abad ke-19 M., melalui empat khalifah Syekh Ahmad Khatib Sambas, yakni: Syekh Abdul Karim Banten, Syekh Ahmad Thalhah, Syaikhona Kholil Bangkalan, dan Syekh Ahmad Hasbullah Madura. Syekh Abdul Karim Banten, setidaknya memiliki empat khalifah besar yang amat getol menyebarkan TQN, yakni: Syekh Asnawi Caringin, Syekh Zarkasyi Berjan Purworejo, Syekh Tubagus Falak Pangentongan, dan Syekh Ibrahim al-Brumbungi Demak. Kemudian, keempat khalifah awal Syekh Abdul Karim ini melahirkan banyak khalifah/mursyid/badal mursyid yang juga besar pengaruhnya, beberapa di antaranya adalah Syekh Nawawi Berjan dan Syekh Ali Secang Magelang (generasi ke-3 TQN jalur Syekh Zarkasyi), Syekh Muslih Abdurrahman Mranggen (generasi ke-3 TQN jalur Syekh Asnawi Caringin dan Syekh Ibrahim Brumbung), dan K.H. Thahir Falak Pangentongan (generasi ke-2 TQN jalur Syekh Tubagus Falak).

70 Roudlatul Ulum, "Profil Singkat KH. Zamrodji al-Mursyid Pendiri PP Raudlatul Ulum Kencong”, http://raudlatululumkencong.blogspot.co.id/2014/03/ kajian-thoriqoh-qodiriyah-wa.html. diakses pada tanggal 12 April 2016., 
Syekh Ahmad Hasbullah al-Maduri di Jawa hanya memiliki satu khalifah, yakni K.H. Muhammad Kholil yang kemudian dilanjutkan oleh K.H. Romly Tamim. Dari tangan adik ipar K.H. Muhammad Kholil ini TQN jalur Syekh Ahmad Hasbullah ini menyebar pesat dan mencetak banyak khalifah/mursyid/badal mursyid, di antaranya K.H. Usman al-Ishaqi dan putranya K.H. Asrori al-Ishaqi (TQN Usmaniyah), K.H. Musta'in Romly (TQN Rejoso), K.H. Adlan Aly (TQN Cukir), K.H. Muhammad Shiddiq (TQN Sholihiyyah Dawe Kudus), dan K.H. Zamroji (TQN Kencong Pare Kediri).

Syekh Ahmad Thalhah memiliki banyak khalifah, namun yang paling mencolok ialah Syekh Mubarok (Abah Sepuh) yang kemudian dilanjutkan oleh putranya K.H. Shohibul Wafa Tajul 'Arifin (TQN Suryalaya). Ditangan Abah Anom, sebutan populer K.H. Shohibul Wafa, TQN jalur Syekh Ahmad Thalhah berkembang sangat pesat tidak hanya di Jawa, namun juga Sumatera, Kalimantan, dan bahkan ke Malaysia, Brunei Darussalam, dan Singapura.

Jalur terakhir ialah jalur Syekhona Khalil Bangkalan. Sayangnya jalur TQN Syekhona Kholil ini tidak banyak diketahui, namun setidaknya terdapat data yang kuat bahwa Habib Ali Negara Bali merupakan salah satu yang mendapatkan ijazah TQN darinya. Habib Ali Negara Bali kemudian mengijazabkannya kepada Habib Luthfi bin Yahya Pekalongan. Jadi, sejauh data yang ada, Habib Luthfi saat ini merupakan satu-satunya pelanjut TQN jalur Syekhona Kholil Bangkalan.

Pada tahun 1970-an, sebagaimana pendapat Dhofier, di Jawa tidak hanya terdapat empat pusat penyebaran TQN, namun sembilan pusat, yakni: (1) TQN Suryalaya dengan mursyid K.H. Shohibul Wafa Tajul 'Arin, (2) TQN Pangentongan dengan mursyid Tubagus Muhammad Falak, (3) TQN Mranggen dengan mursyid K.H. Muslih Abdurrahman, dan (4) TQN Rejoso dengan mursyid K.H. Musta'in Romly, (5) TQN Berjan Purworejo dengan mursyid K.H. Nawawi bin Muhammad Shiddiq 
bin Zarkasyi, (6) TQN Al-Utsmaniyah Sawah Pulo Surabaya -kemudian pindah ke Kedinding- dengan mursyid K.H. Uthman al-Ishaqi, (7) TQN Cukir Jombang dengan mursyid K.H. Adlan Aly, (8) TQN Kencong Pare Kediri dengan mursyid K.H. Zamroji, dan (9) TQN As-Shalihiyah Dawe Kudus dengan mursyid K.H. Muhammad Shiddiq.

\section{Referensi}

Aqib, Kharisudin. Al Hikmah, Memahami Teosofi Tarekat Qodariyah wa Naqsabandiyah, edisi revisi. Surabaya: Dunia Ilmu, 2000.

Adlina, Atika Ulfia. "Pengalaman Mistik Pengikut TQN Dawe Kudus." Analisa, Vol. 19, No. 01, (2012): 37-54

Bruinessen, Martin Van. Kitab Kuning: Pesantren dan Tarekat. Bandung: Mizan, 1995.

Bruinessen, Martin Van. Tarekat Naqshabandiyah di Indonesia. Bandung: Mizan, 1996.

Bruinessen, Martin Van. "Shari'a Court, Tarekat and Pesantren: Religious

Institutions in the Banten Sultanate." dalam Archipel, Vol. 50, (1995): 165-199.

Bruinessen, Martin Van. "Muslih b. 'Abd al-Rahman al-Maraqi". dalam Dictionnaire Biographique des Savamts et Grandes du Monde Musulman Peripherique, du XIXe Siecle a Nos Jours, Fasc., No. 2, Paris: CNRSEHESS, (1998): 23-24.

Dhofier, Zamakhsyari. Tradisi Pesantren: Studi tentang Pandangan Hidup Kiai. Jakarta:LP3ES, 1985.

Danusiri. "Menumbuhkan Potensi Beragama Kaum Tarekat Qadiriyah wa Naqsyabandiyah Dawe Kudus." dalam Jurnal Analisa, Vol. 19, No. 01, (2012): 27-36

Fauzia, Amelia. Faith and the State: A History of Islamic Philanthropy in Indonesia. Leiden: Brill, 2013.

Hadi, Mahfudz. Berjuang Di Tengah Gelombang, Biografi dan Perjuangan Syaikhona Mohammad Kholil bin Abdul Latief Bangkalan Madura. Surabaya:eLKAF, 2010. 
Haidar, M. Ali. "Tarekat Qodariyah wa Naqsabandiyah Syekhona Muhammad Kholil Bangkalan Tahun 1834-1925." dalam Jurnal Avatara, Vol 1, No.2, (2013): 89-99.

al Jabbar, Umar 'Abd, Siyar wa. Tarajim ba'd 'Ulama'ina fi al Qarn al Rabi' Ashar lil Hijra. Jeddah: Tihama, 1982.

Jonsen, Mahmud. “DaftarWakil Talqin TQN PPS”, http:/ / mahmudjonsen. blogspot.co.id. diakses pada tanggal 12 April 2016.

Kartodirjo, Sartono. Pemberontakan Petani Banten 1888. Jakarta: Pustaka Jaya, 1984.

Kurnianto, Rido. "Kajian Makna Simbol Kupu-Kupu Terbang Ke Langit Pada Tarekat Qadiriyah Naqshabandiyah Suryalaya Tasikmalaya." Maraji': Jurnal Studi Keislaman. Vol. 2. No. 2. (2016): 382-399.

Lubis, Nina H, dkk.. Sejarah Perkembangan Islam di Jawa Barat. .tkp: tp, tt.

Mulyati, Sri, et al.. Mengenal dan Memahami Tarekat Tarekat Muktabarah di Indonesia. Jakarta: Kencana, 2006.

Mulyati, Sri. Tasawuf Nusantara: Rangkaian Mutiara Sufi Terkemuka. Jakarta: Kencana, 2006.

Masyhuri, Ahmad Aziz. Ensiklopedi 22 Aliran Tarekat dalam Tasawuf. Surabaya: Imtiyaz, 2011.

Mu'min, Ma'mun. "Sejarah Tarekat Qodiiriyah wan Naqsabandiyah Piji Kudus", Fikrah. Vol. 2. No. 1. (2014): 357-377.

Nawawi, Achmad Chalwani. "Mengenal Tarekat di Berjan Purworejo", disampaikan pada audiensi dalam rangka penelitian mahasiswa UI Jakarta di PP an Nawawi Berjan, 08 Juni 2008.

Rahmad, Dadang. Tarekat dalam Islam: Spiritualitas Masyarakat Modern. Bandung: Pustaka Setia, 2002.

Rifat, R. Ahmad Maduki. "Pemikiran KH. Achmad Asrori al-Ishaqy", Sinopsis Tesis UIN Walsongo 2011.

Roudlatul Ulum. "Profil Singkat KH. Zamrodji al-Mursyid Pendiri PP Raudlatul Ulum Kencong." http://raudlatululumkencong. blogspot.co.id/2014/03/kajian-thoriqoh-qodiriyah-wa.html. diakses pada tanggal 12 April 2016.

Tarling, Nicholas, ed.. The Cambridge History of Southeast Asia Vol II: The Nineteenth and Twentieth Centuries. New York: Cambridge Press, 1992. 
Tim PP an-Nawawi. Mengenal KH. Nawawi Berjan Purworejo. Surabaya: Khalista, 2008.

Turmudi, Endang. Struggling for The Ulama: Changing Leadership Roles of Kiai in Jombang East Java. UNU: E Press, 2006.

Ulum, M. Misbahul. "Biografi KHM Munawwir Musthofa al-Mursyid." http://kol-il.blogspot.co.id/2015/02/biografi-kh-m-munawwirmusthofa-al.html, diakses pada tanggal 26 Mei 2016.

Wikipedia. "Muhammad Luthfi bin Yahya." https://id.wikipedia.org/ wiki/Muhammad_Luthfi_bin_Yahya, diakses pada tanggal 21 Mei 2016.

Widiyanto, Asfa. "Manaqib Writing in The Circle of The Tariqa Qadiriyya wa Naqsyabandiyyah: A Study on Muhammad Siddiq al-Salihi's Nayl al-Amani." Heritage of Nusantara. Vol. 4. No. 2. (2015): 213242.

KH. Wahfiudin dalam acara Khidmat Ilmiah Manaqib pada tanggal 23 Januari 2013 di Pon. Pes. Suryalaya.

Zulkifli. Sufism in Java: The Role of Pesantren in The Maintenance of Sufism in Java, Jakarta: INIS, 2002.

Zuhdi, Zaenu. "Ibadah Penganut Tarekat: Studi Tentang Afiliasi Madhab Fikih Tarekat Qadiriyah wa Naqshabandiyah, Shiddiqiyyah dan Shadhiliyah di Jombang.” Disertasi UIN Sunan Ampel 2013.

Surat Keputusan Ijma' Wakil Talqin TQN PP Suryalaya dan Ahli Waris Syekh Mursyid KH. Ahmad Shohibul Wafa' Tajul Arifin Ra 